\title{
Recurrent Hemoptysis in Patient with Primary Pulmonary Hypertension - A Case Report and Literature Review
}

\author{
Indra Widya Nugraha*, Bambang Irawan, Lucia Kris Dinarti \\ Department of Cardiology and Vascular Medicine, Faculty of Medicine, Universitas Gadjah Mada University - Dr. Sardjito \\ General Hospital, Yogyakarta, Indonesia \\ ${ }^{*}$ Corresponding author: \\ Indra Widya Nugraha, MD - email: indrawidya@yahoo.com \\ Department Cardiology and Vascular Medicine, Faculty of Medicine, Universitas Gadjah Mada - Dr. Sardjito Hospital, \\ Jalan Farmako Sekip Utara Yogyakarta, 55281, Indonesia.
}

Manuscript submitted: September 24, 2017; Revised and accepted: October 10, 2017

\begin{abstract}
Pulmonary hypertension $(\mathrm{PH})$ is defined as an increase in mean pulmonary arterial pressure $(\mathrm{mPAP}) \geq 25 \mathrm{mmHg}$ at rest as assessed by right heart catheterization (RHC). The symptoms of $\mathrm{PH}$ are non-specific and mainly related to progressive right ventricular (RV) dysfunction. In some patients the clinical presentation may be related to mechanical complications of $\mathrm{PH}$ and the abnormal distribution of blood flow in the pulmonary vascular bed, include hemoptysis related to rupture of hypertrophied bronchial arteries. Hemoptysis is a serious complication that is rarely reported in patients with pulmonary arterial hypertension (PAH). Hemoptysis severity ranges from mild to very severe leading tosudden death. Hemoptysis are reported to be a terminal stage of a complication due to $\mathrm{PAH}$ with prevalence is variable, from $1 \%$ to $6 \%$. Although the incidence is quite rare, the presence of recurrent hemoptysis in patients with pulmonary hypertension is a sign of poor prognosis. Bronchial artery embolization is suggested as an acute emergency procedure in the case of severe hemoptysis or as elective intervention in cases of frequent mild or moderate episodes.
\end{abstract}

Keywords: Pulmonary Hypertension; Hemoptysis; Bronchial artery embolization

\section{Intisari}

Hipertensi pulmonal (HP) didefinisikan sebagai peningkatan rerata tekanan arteri pulmonal $\geq 25$ $\mathrm{mmHg}$ saat istirahat yang diukur dengan kateterisasi jantung kanan (KJK). Gejala-gejala dari HP tidak spesifik dan terutama berhubungan dengan difungsi ventrikel kanan yang progresif. Pada beberapa pasien, presentasi klinis mungkin berhubungan dengan komplikasi mekanis HP dan distribusi aliran darah yang tidak normal pada pulmonary vascular bed, termasuk hemoptisis yang berhubungan dengan hipertrofi arteri bronkhialis. Hemoptisis merupakan komplikasi serius yang jarang dilaporkan pada pasien dengan hipertensi arteri pulmonal (HAP). Keparahan hemoptisis berkisar dari ringan sampai sangat berat yang menyebabkan kematian mendadak. Hemoptisis dilaporkan merupakan stadium terminal dari komplikasi HAP dengan prevalensi bervariasi, dari $1 \%$ sampai $6 \%$. Meskipun insidensi sangat jarang, adanya hemoptisis berulang pada pasien dengan HP merupakan petanda prognosis yang buruk. Embolisasi arteri bronkhialis dilaporkan sebagai tindakan kegawatan pada kasus hemoptisis berat atau sebagai tindakan elektif pada kasus episode ringan atau sedang yang berulang.

\section{INTRODUCTION}

Pulmonary hypertension $(\mathrm{PH})$ is a pathophysiological disorder that encompasses various clinical conditions and could be a complication of cardiovascular disease and respiration. Based on the 2015 ESC/ERS Guidelines for the diagnosis and treatment of pulmonary hypertension, pulmonary hypertension is defined as an increase in mean pulmonary arterial pressure $(\mathrm{mPAP}) \geq 25 \mathrm{mmHg}$ at rest, 
with the assessment of right heart catheterization (RHC). ${ }^{1}$ Pulmonary Artery Hypertension (PAH) is one of the subtypes of $\mathrm{PH}$ characterized by pre-capillary pulmonary hypertension, defined as pulmonary artery wedge pressure (PAWP) $\leq 15$ $\mathrm{mmHg}$ and Pulmonal Vascular Resistance (PVR) $>3$ Wood Unit (WU), in the absence of other causes of pulmonary pre-capillary hypertension, such as pulmonary hypertension associated with pulmonary disease, chronic thromboembolic pulmonary hypertension (CTEPH), or other rare diseases. ${ }^{1}$

Microscopically, $\mathrm{PAH}$ is characterized by intimal hyperplasia, hypertrophy of the tunica media, thickening of the tunica adventitia, and endothelial proliferation. The disease was first discovered by Dr. Ernst von Romberg in 1891.2,3 The incidence of $\mathrm{PAH}$ is very rare, where in France the incidence is only 15 cases for every million people. . $^{2,3}$

Hemoptysis is a serious complication that is rarely reported in patients with pulmonary arterial hypertension (PAH). Hemoptysis is reported to be a terminal stage of a complication due to $\mathrm{PAH}$. The incidence of hemoptysis in $\mathrm{PAH}$ patients remain uncertain and tend to be unreported. Similarly, the patho-mechanism of hemoptysis in $\mathrm{PAH}$ remains uncertain. ${ }^{4}$ Mortality associated with hemoptysis in $\mathrm{PAH}$ is influenced by multifactorial. Some evidence suggests that patients with $\mathrm{PAH}$ who are associated with congenital heart disease have a better prognosis for their hemoptysis complications than other PAH types. However, the underlying mechanisms of this condition remain unknown. ${ }^{4,5}$

\section{CASE PRESENTATION}

We reported the case of a 25-year-old woman who came to the Dr. Sardjito Hospital Emergency Hospital with a chief complaint of hemoptysis. On the day of admission, the patient complained of coughing up blood and shortness of breath. The blood was bright red with a total of about $400 \mathrm{~mL}$. Complaints of fever, chest pain, back pain, nausea or vomiting are refuted. The patient then immediately goes to the Emergency Room of Dr. Sardjito Hospital.

Past medical history: The patient has had previous similar complaints and has been hospitalized several times in Sardjito Hospital. The patient was last hospitalized in Sardjito Hospital in November 2015 with a diagnosis Primary Pulmonary Artery Hypertension (PAH) high resistance non-reactive $\mathrm{O}_{2}$ test, observation of hemoptysis suspected to be associated with pulmonary hypertension. Patients received routine therapy with sildenafil $40 \mathrm{mg}$ t.i.d, digoxin $0.25 \mathrm{mg}$ q.i.d, codeine (if necessary), beraprost $20 \mathrm{mg}$ t.i.d. furosemide $20 \mathrm{mg}$ q.i.d. History of hypertension, diabetes mellitus, hormonal contraceptive use and family history with similar complaints are denied.

In physical examination, the general condition is sufficient, compos mentis mental state, with a slightly shortness of breath. The vital sign is blood pressure 90/70 mmHg, pulse $110 \mathrm{x} /$ minute, respiratory rate $28 \mathrm{x} /$ minute, body temperature: $36.9^{\circ} \mathrm{C}$ and peripheral oxygen saturation is $92 \%$ (with oxygen nasal cannula 4 liters per minute). Head examination is within normal limits. Neck examination shows increased jugular venous (5+4 $\mathrm{cm} \mathrm{H}_{2} \mathrm{O}$ ). Thechest examination shows symmetrical movement without any abnormality in inspection, palpation, percussion, and auscultation of the lung. Cardiac examination reveals cardiomegaly with RV heaving (+), $2^{\text {nd }}$ heart sound waslouder, pansystolic murmurgrade $3 / 6$ with punctum maximum atleft lower sternal border. Abdominal examination are within normal limits and there was no peripheral edema.

From the electrocardiography (ECG) examination showed sinus rhythm with heart rate 120x / minute, Right Axis Deviation (RAD), Right Ventricle Hypertrophy (RVH), Right Atrial Enlargement (RAE) (Figure 1). From the chest $\mathrm{x}$-ray examination there is cardiomegaly (CTR: 0.58 ) with aortosclerosis and bilateral pneumonia (Figure 2). 
From the laboratory examination shows hemoglobin level $10.6 \mathrm{~g} / \mathrm{dL}$, platelet count $417.000 /$ $\mu \mathrm{L}$, and increased leukocyte count $22.950 / \mu \mathrm{L}$ with the dominance of segment (Segment: $82.8 \%$, Lymphocyte $11.6 \%$, Monocyte $5.1 \%$ ). The blood chemistry shows BUN $10.5 \mathrm{mg} / \mathrm{dL}$, creatinine $0.79 \mathrm{mg} / \mathrm{dL}$, Albumin $4.55 \mathrm{mg} / \mathrm{dL}$, SGOT $24 \mathrm{U} / \mathrm{L}$, SGPT $17 \mathrm{U} / \mathrm{L}$, random blood glucose $111 \mathrm{mg} / \mathrm{dL}$. Electrolyte examination showed the presence of hypokalemia with potassium level $2.9 \mathrm{mEq} /$ $\mathrm{dL}$, sodium $136 \mathrm{mEq} / \mathrm{dL}$, Chloride: $90 \mathrm{mEq} / \mathrm{L}$. Examination of bleeding diastases within normal limits with PPT: 19.1 (control 15.2), APTT: 24.9 (control 33.3), INR: 1.51.

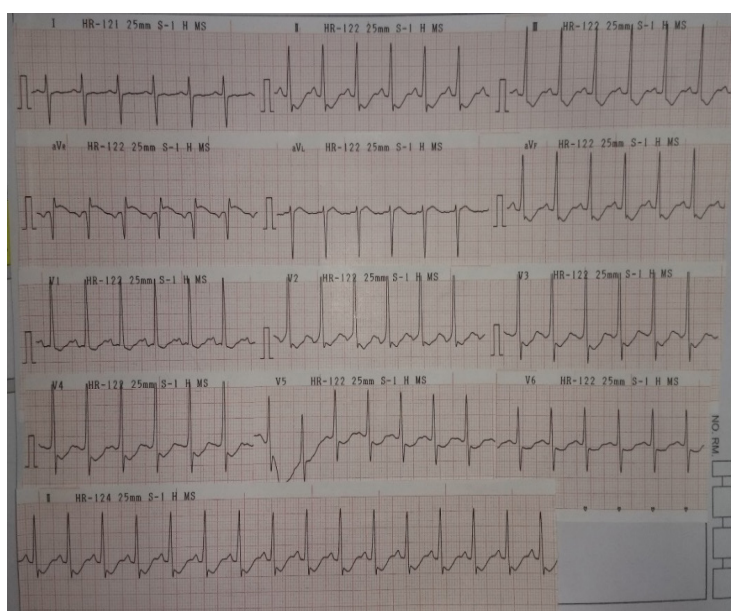

Figure 1. The ECG showed Sinus Rhythm with heart rate $120 \mathrm{x} /$ minute, Right Axis Deviation (RAD), Right Ventricle Hypertrophy (RVH), Right Atrial Enlargement (RAE)

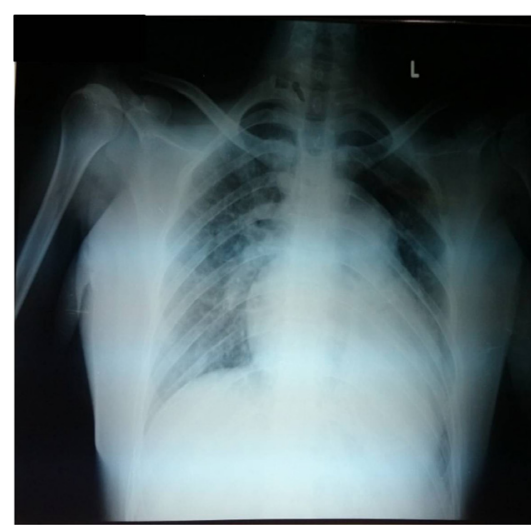

Figure 2. The Chest $X$-Rays showed cardiomegaly (CTR: 0.58) with aortosclerosis and bilateral pneumonia
From echocardiography examination shows RA and RV dilatation (LVIDs $29 \mathrm{~mm}$, LVIDs 16 mm, LVPWd 6 mm, RA 49 mm, RV 37 $\mathrm{mm}$ ); Global LV systolic function normal with EF 77\%; LV diastolic dysfunction: relaxation type; Decreased of RV systolic function (TAPSE 14); IVS paradox (LV D-shaped). Mild MR, moderate TR (TVG $121 \mathrm{mmHg}$ ), PH severe (Figure 3).

From the Chest Computed Tomography examination showsa dilation of the pulmonary truncus with diameter $\pm 3.59 \mathrm{~cm}$, dilatation of the right pulmonary artery with diameter \pm 2.69 $\mathrm{cm}$, dilatation of the left pulmonary artery with diameter $\pm 2.51 \mathrm{~cm}$, and dilatation of the bilateral pulmonary artery branches. The diameter of the pulmonary truncus is greater than the ascending aortic aorta; There is enlargement of the right atrium and the right ventricle. Conclusion: Dilatation of the pulmonary artery that supports the diagnosis of pulmonary hypertension (Figure 4).

Patients have also performed right heart catheterization in the previous hospitalization (April 20, 2015), with results: Primary pulmonary hypertension. Pre $\mathrm{O} 2$ test: $\mathrm{mPAP}=98 \mathrm{mmHg}$, Pulmonary Artery Resistance Index (PARI) = 39. Post $\mathrm{O} 2$ test: $\mathrm{mPAP}=99 \mathrm{mmHg}, \mathrm{PARI}=35$. Conclusion: primary pulmonary hypertension, high resistance, non reactive with $\mathrm{O} 2$ test.

Patients were diagnosed with primary pulmonary arterial hypertension non-reactive O2 test, observation of hemoptysis suspected to be associated with pulmonary hypertension, suspected Health Care-Associated Pneumonia (HCAP) andhypokalemia. The treatments were: sildenafil 40 t.i.d. $\mathrm{mg}$, digoxin $0.25 \mathrm{mg}$ q.i.d., furosemide $20 \mathrm{mg}$ q.i.d., iloprost nebulizer 2.5 mcg q.i.d., Aspar K 1 tablet q.i.d., intravenous ceftazidime $1 \mathrm{gr}$ t.i.d., intravenous ciprofloxacin 400 mgb.i.d. 


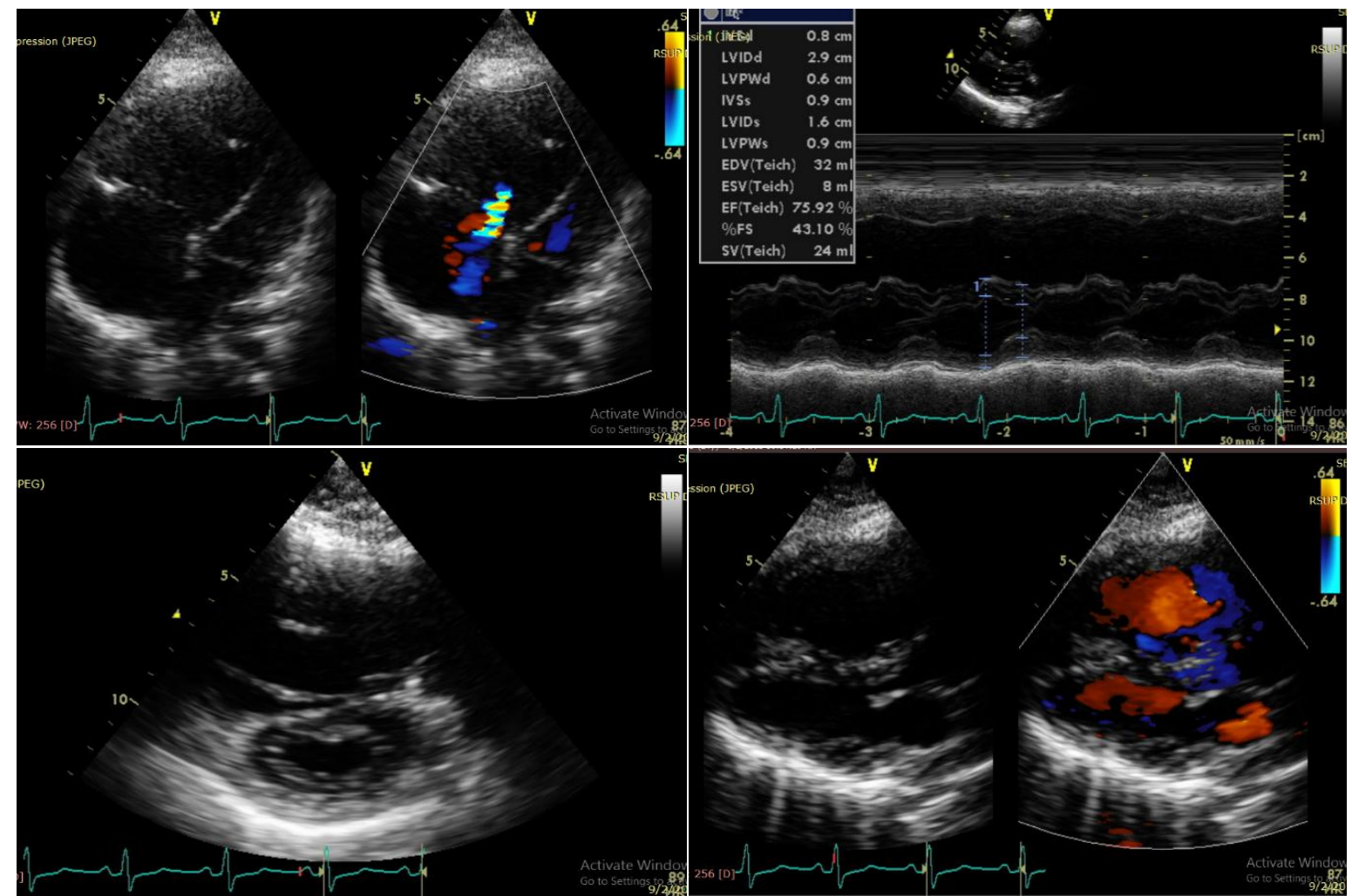

Figure 3. The Echocardiography showed RA and RV dilatation; Global LV systolic function normal with EF 77\%; LV diastolic dysfunction: relaxation type; Decreased of RV systolic function; IVS paradox (LV D-shaped); Mild MR, moderate TR, PH severe

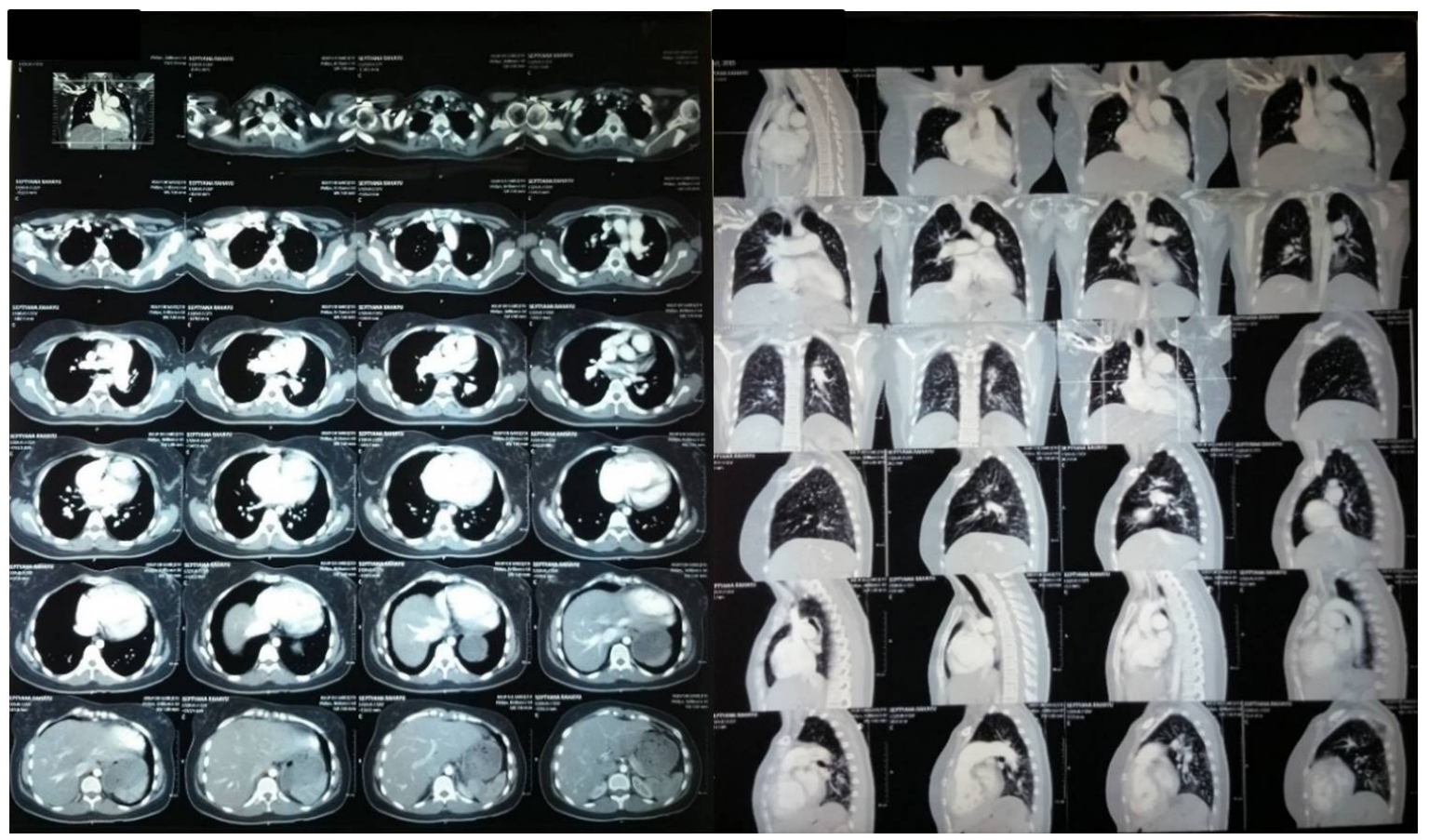

Figure 4. The Chest Computed Tomography examination showed dilatation of the pulmonary artery that supports the diagnosis of pulmonary hypertension 


\section{Discussion}

Diagnosis of pulmonary hypertension is established by taking a comprehensive look at clinical signs and symptoms, physical examination results, and the results of additional investigations. Examination results are used to confirm the hemodynamic criteria of Pulmonary Hypertension as well as to explain the etiology and severity of the disease. ${ }^{1}$ In accordance with the 2015 ESC/ERS Guidelines of pulmonary hypertension, diagnosis of pulmonary hypertension can be established if there is an increase in mean pulmonary arterial pressure $(\mathrm{mPAP}) \geq 25 \mathrm{mmHg}$ at rest, as measured by right heart catheterization (RHC). Clinically, Pulmonary Hypertension is grouped into 5 subtypes, as shown in Table 1.1,6

Based on the 2015 ESC/ERS Guidelines of Pulmonary Hypertension, diagnosis of Pulmonary Hypertension is established by following the algorithm flow as shown in Table 1. Based on the algorithm flow of the ESC guideline, anamnesis and physical examination is the initial modality in diagnosing Pulmonary Hypertension. But often the disease at an early stage is usually asymptomatic. The disease usually progresses with symptoms that vary widely, ranging from mild to severe. Generally patients complain of shortness of breath that is getting worse, malaise, unproductive cough, fainting or syncope, peripheral edema and sometimes hemoptysis, which is rare in most patients. There is usually no symptom of orthopnea and paroxysmal nocturnal dyspnea..$^{1,7}$

Physical examination is relatively insensitive to make the diagnosis, but it can help to rule out the differential diagnosis. If on lung examination found wheezing and rales, should be considered the possibility of bronchial asthma, bronchitis or fibrosis. Rales as seen in congestive

Table 1. Clinical Classification of Pulmonary Hypertension ${ }^{1}$

\begin{tabular}{|l|}
\hline I. Pulmonary arterial hypertension \\
\hline I.I Idiopathic \\
I.2 Heritable \\
I.2.I BMPR2 mutation \\
I.2.2 Other mutations \\
I.3 Drugs and toxins induced \\
I.4 Associated with: \\
I.4.I Connective tissue disease \\
I.4.2 Human immunodeficiency virus (HIV) infection \\
I.4.3 Portal hypertension \\
I.4.4 Congenital heart disease (Table 6) \\
I.4.5 Schistosomiasis \\
\hline I'. Pulmonary veno-occlusive disease and/or pulmonary \\
capillary haemangiomatosis \\
\hline I'.I Idiopathic \\
I'.2 Heritable \\
I'.2.I EIF2AK4 mutation \\
I'.2.2 Other mutations \\
I'.3 Drugs, toxins and radiation induced \\
I'.4 Associated with: \\
I'.4.I Connective tissue disease \\
I'.4.2 HIV infection \\
\hline I". Persistent pulmonary hypertension of the newborn \\
\hline 2. Pulmonary hypertension due to left heart disease \\
\hline 2.I Left ventricular systolic dysfunction \\
2.2 Left ventricular diastolic dysfunction \\
2.3 Valvular disease \\
2.4 Congenital / acquired left heart inflow/outflow tract \\
obstruction and congenital cardiomyopathies \\
2.5 Congenital /acquired pulmonary veins stenosis \\
\hline
\end{tabular}

Source: Galie et al. (2015)

\begin{tabular}{|c|}
\hline $\begin{array}{l}\text { 3. Pulmonary hypertension due to lung diseases and/or } \\
\text { hypoxia }\end{array}$ \\
\hline $\begin{array}{l}\text { 3.I Chronic obstructive pulmonary disease } \\
\text { 3.2 Interstitial lung disease } \\
\text { 3.3 Other pulmonary diseases with mixed restrictive and } \\
\text { obstructive pattern } \\
\text { 3.4 Sleep-disordered breathing } \\
\text { 3.5 Alveolar hypoventilation disorders } \\
\text { 3.6 Chronic exposure to high altitude } \\
\text { 3.7 Developmental lung diseases (Web Table III) }\end{array}$ \\
\hline $\begin{array}{l}\text { 4. Chronic thromboembolic pulmonary hypertension } \\
\text { and other pulmonary artery obstructions }\end{array}$ \\
\hline $\begin{array}{l}\text { 4.I Chronic thromboembolic pulmonary hypertension } \\
\text { 4.2 Other pulmonary artery obstructions } \\
\text { 4.2.I Angiosarcoma } \\
\text { 4.2.2 Other intravascular tumors } \\
\text { 4.2.3 Arteritis } \\
\text { 4.2.4 Congenital pulmonary arteries stenoses } \\
\text { 4.2.5 Parasites (hydatidosis) }\end{array}$ \\
\hline $\begin{array}{l}\text { 5. Pulmonary hypertension with unclear and/or } \\
\text { multifactorial mechanisms }\end{array}$ \\
\hline $\begin{array}{l}\text { 5.I Haematological disorders: chronic haemolytic anaemia, } \\
\text { myeloproliferative disorders, splenectomy } \\
\text { 5.2 Systemic disorders: sarcoidosis, pulmonary histiocytosis, } \\
\text { lymphangioleiomyomatosis, neurofibromatosis } \\
\text { 5.3 Metabolic disorders: glycogen storage disease, Gaucher } \\
\text { disease, thyroid disorders } \\
\text { 5.4 Others: pulmonary tumoral thrombothic microangiopathy, } \\
\text { fibrosing mediastinitis, chronic renal failure (with/without } \\
\text { dialysis), segmental pulmonary hypertension }\end{array}$ \\
\hline
\end{tabular}


heart failure shows left heart failure. Louder of $2^{\text {nd }}$ heart sounds in the pulmonary region can be found in nearly $90 \%$ of patients with advanced $\mathrm{PH}$ when right heart failure occurs. In addition, symptoms and signs such as gallop, jugular venous distention, liver or spleen enlargement or both, ascites or peripheral edema may be present. $^{8}$

In this case report, the diagnosis of $\mathrm{PH}$ has generally followed the algorithm in the 2015 ESC/ ERS Guidelines of Pulmonary Hypertension. Nevertheless, there are some examinations that can not be done because of limited facilities and not routinely done in Dr. Sardjito Hospital, such as V/Q Scan Pulmonary examination, CT Scan Pulmonary Angiography, and genetic examination.

In accordance with the 2015 ESC/ERS Guidelines of Pulmonary Hypertension above, the diagnosis of $\mathrm{PH}$ requires a variety of additional investigations to definitively diagnose, exclude the differential diagnosis, and to determine the clinical classification of pulmonary hypertension. ${ }^{1}$. The investigations that may be used to confirm the diagnosis of pulmonary hypertension include: ${ }^{1,8}$

- Electrocardiography

- Chest X ray

- Echocardiography

- Ventilation / Perfusion Lung Scan

- CT Pulmonary Angiography

- Right Heart Catheterization with / without pulmonary angiography

- Special / specific investigations

\section{Electrocardiography (ECG)}

On ECG examination patients with pulmonary hypertension sometimes show a right axis deviation and right atrial hypertrophy (RV) image. But often it is not significant. Chronic pulmonary emphysema can reduce the electrical voltage of the ECG and mask the signs of hypertrophy. ${ }^{9}$ The ECGof the patient in this case report supports the presence of pulmonary hypertension, in which the ECG shows the presence of Right Axis Deviation (RAD), Right Ventricle Hypertrophy $(\mathrm{RVH})$, and Right Atrial Enlargement (RAE)

\section{Chest Radiography}

Chest $\mathrm{x}$-rays could show the presence ofpulmonary artery dilatation, underlying pulmonary disease, pulmonary perfusion defects (e.g. in patients with chronic thromboembolism), and also cardiomegaly. ${ }^{9}$ The chest X-ray of patients proposed in this case report supports the presence of pulmonary hypertension, wherein from chest $X$-ray image there is presence ofcardiomegaly ( $\mathrm{RV}$ dilatation).

\section{Echocardiography}

In the 2015 ESC/ERS Guidelines of Pulmonary Hypertension, Echocardiography is recommended as a first-line non-invasive diagnostic test. Transthoracic echocardiography (TTE) is a non-invasive screening examination for pulmonary hypertension. Echocardiography examination may assess pulmonary artery pressure that equivalent to right ventricular systolic pressure, as long as there is no pulmonary outflow obstruction. The examination may also provide information about the causes of pulmonary hypertension including right and left ventricular dimensions and functions, vascular abnormalities, right ventricular ejection, left ventricular filling characteristics and pericardial effusion. ${ }^{1,7,9}$

The results of echocardiography examination in this case report also support the diagnosis of pulmonary hypertension, which the results showed: RA and RV dilatation (LVIDs 29 mm, LVIDs 16 mm, LVPWd 6 mm, RA 49 mm, RV $37 \mathrm{~mm}$ ); Global LV systolic function normal with EF 77\%; LV diastolic dysfunction: relaxation type; Decreased of RV systolic function (TAPSE 14); IVS paradox (LV D-shaped). Mild MR, moderate TR (TVG $121 \mathrm{mmHg}$ ), PH severe. 


\section{Cardiac Magnetic Resonance Imaging}

Cardiac magnetic resonance imaging (CMRI) is not included in the recommended support modalities in the 2015 ESC/ERS Guidelines. However, CMRI examination can accurately measure the magnitude and function of the left and right ventricle. Examination of right ventricular function is important for prognosis and indicators of Pulmonary Hypertension. From MRI examination, it can be measured: function, stroke volume whether $\leq 25 \mathrm{~mL} / \mathrm{m}^{2}$, diastolic final volume of $\geq 84 \mathrm{~mL} / \mathrm{m}^{2}$, and end-diastolic ventricular volume $\leq 40 \mathrm{~mL} / \mathrm{m}^{2} .{ }^{10,11}$

\section{Right Heart Catheterization}

Not all of patients suspected with pulmonary hypertension should undergo invasive examination such as right heart catheterization (RHC). Some patients are adequately diagnosed by non-invasive methods such as echocardiography. However, if the diagnosis still cannot be enforced, then the patient needs to undergo invasive examination such as RHC. Right heart catheterization is performed to confirm the diagnosis of $\mathrm{PAH}$, assess the degree of severity, and assess the vasodilatation response of the drug or high concentration oxygen. In addition, pulmonary arteriography examination may also show the presence of thromboembolic disease..$^{1,12}$

In this case report, the result of $\mathrm{RHC}$ of the patient support the diagnosis of pulmonary arterial hypertension, where the mean pulmonary arterial pressure $(\mathrm{mPAP})=98 \mathrm{mmHg}$, pulmonary artery wedge pressure (PAWP) value $=11 \mathrm{mmHg}$ and Pulmonary Artery Resistance Index (PARI) $=39$. This value corresponds to the diagnostic criteria of Pulmonary Artery Hypertension (PAH). In the patients presented in this case report, all ofthe examination led to a diagnosis of Pulmonary Artery Hypertension. This is based on signs and symptoms, the results of physical examination and various investigations that have been done such as ECG, chest x-ray, echocardiography, and especially the results of the $\mathrm{RHC}$ examination.

Pulmonary Artery Hypertension (PAH) is one of the subtypes of $\mathrm{PH}$ characterized by pre-capillary pulmonary hypertension, defined as pulmonary artery wedge pressure (PAWP) $\leq 15$ $\mathrm{mmHg}$ and Pulmonal Vascular Resistance (PVR) $>3$ Wood Unit (WU), in the absence of other causes of pulmonary pre-capillary hypertension, such as pulmonary hypertension associated with pulmonary disease, chronic thromboembolic pulmonary hypertension (CTEPH), or other rare diseases. ${ }^{1}$

\section{Pathophysiology of Pulmonary Artery Hypertension}

Pulmonary arterial hypertension (PAH) is a serious disease in which there is progressive pulmonary vascular resistance that can lead to right ventricular failure and death. Microscopically, $\mathrm{PAH}$ is characterized by intimal hyperplasia, hypertrophy of the tunica media, thickening of the tunica adventitia, and endothelial proliferation. In $\mathrm{PAH}$ there is an increase in pulmonary vascular resistance resulting in decreased right ventricular function due to afterload. The main cause of increased vascular resistance is remodeling due to excessive cell proliferation and decreased apoptosis. In addition, vasoconstriction plays an important role in about $20 \%$ of patients. ${ }^{3,10}$

In PAH occurs various pathological changes such as endothelial dysfunction, decreased apoptosis or proliferation ratio of pulmonary artery smooth muscle cells, tunica intima and media thickening, tunica adventitia abnormalities, and activation of excessive metalloproteases adventitious that similar to cancer and atherosclerosisprocess. In $\mathrm{PAH}$, production of vasoconstrictors such as endothelin and thromboxane by endothelium increases, but on the other hand there is a decrease in the production of vasodilators such as prostacyclin. ${ }^{3,13}$ 
In addition, in the lumen of a patient's blood vessel with $\mathrm{PAH}$, an elevated plasma serotonin level was found. Serotonin can stimulate the proliferation of smooth cardiac muscle cells and it is an important sign in the pathogenesis of PAH. Nitric oxide (NO) produced in the endothelial is a vasodilator that will inhibit platelet activation and vascular smooth muscle cell proliferation formed from three nitric oxide isoforms (NOs / S / NOS3). However, the role of NO in PAH pathophysiology remains unclear. Pulmonary arterial hypertension has a poor prognosis and high mortality, despite adequate treatment. ${ }^{13,14}$

Clinically, in pulmonary arterial hypertension (PAH), there are several groups of patients with increased pulmonary artery pressure where the underlying cause is unclear. In this group, there was an increase in pulmonary arterial pressure but without an increase in pulmonary arterial wedge pressure. In this patient, the diagnosis of primary pulmonary hypertension is established clinically. From the clinical clustering of primary pulmonary hypertension, there are 3 different histopathologic features: 1) plexogenic pulmonary arteriopathy, 2) recurrent pulmonary thromboembolism, and 3 ) veno-occlusive pulmonary disease. ${ }^{7}$

In primary pulmonary hypertension type plexogenic, characterized initially by pulmonary artery vasoconstriction and tunica media hypertrophy. Next will be followed by the proliferation of tunica intima, including the development of plexiform lesions. In recurrent pulmonary Thromboembolism type, it is characterized by the presence of arterial thrombus of varying sizes that involving pulmonary artery with microscopic size. Thrombus in recurrent pulmonary thromboembolism type, can be derived from embolism or in situ development. While the histopathological features of pulmonary hypertension withveno-occlusive pulmonary disease type, are characterized by obstructive lesions of the pulmonary venous and venules. Clinical presentation of the above three pathological types can be very similar, where the definitive diagnosis is confirmed by histopathological examination of lung tissue taken by biopsy or necropsy. ${ }^{7}$

\section{Pathophysiology of Hemoptysis in Pulmonary Artery Hypertension \\ Hemoptysis is defined as a coughing of blood whose source originates from the lungs or bronchial tubes, as a result of pulmonary or bronchial haemorrhage. Hemoptysis is divided into massive and non-massive based on the coughed blood volume. However, there is no}

Table 2. Differential Diagnosis of Hemoptysis ${ }^{15}$

\begin{tabular}{|c|c|c|}
\hline \multicolumn{3}{|c|}{ Differential Diagnosis of Hemoptysis } \\
\hline $\begin{array}{l}\text { Source other than the lower } \\
\text { respiratory tract }\end{array}$ & $\begin{array}{l}\text { Pulmonary parenchymal source } \\
\text { Lung abscess }\end{array}$ & $\begin{array}{l}\text { Primary vascular source } \\
\text { Arteriovenous malformation }\end{array}$ \\
\hline Upper airway (nasopharyngeal) bleeding & Pneumonia & Pulmonary embolism \\
\hline Gastrointestinal bleeding & Tuberculosis & Elevated pulmonary venous pressure \\
\hline Tracheobronchial source & Mycetoma ("fungus ball") & (especially mitral stenosis) \\
\hline $\begin{array}{l}\text { Neoplasm (bronchogenic carcinoma, } \\
\text { endobronchial metastatic tumor, } \\
\text { Kaposi's sarcoma, bronchial carcinoid) }\end{array}$ & $\begin{array}{l}\text { Goodpasture's syndrome } \\
\text { Idiopathic pulmonary } \\
\text { hemosiderosis }\end{array}$ & $\begin{array}{l}\text { Pulmonary artery rupture secondary to } \\
\text { balloon-tip pulmonary artery catheter } \\
\text { manipulation }\end{array}$ \\
\hline Bronchitis (acute or chronic) & Wegener's granulomatosis & Miscellaneous and rare causes \\
\hline Bronchiectasis & Lupus pneumonitis & Pulmonary endometriosis \\
\hline Broncholithiasis & Long contusion & $\begin{array}{l}\text { Systemic coagulopathy or use of } \\
\text { anticoagulants or thrombolytic agents }\end{array}$ \\
\hline $\begin{array}{l}\text { Airway trauma } \\
\text { Foreign body }\end{array}$ & & \\
\hline
\end{tabular}

Source: Badner, JL \&Pachner RW. $2005^{15}$ 
uniform definition for the classification. Some literature defined hemoptysis as non-massive if the coughed blood volume is $\leq 200 \mathrm{~mL}$ per day. In general, the differential diagnosis of hemoptysis could be seen in table $2 .{ }^{15}$

Hemoptysis is a serious complication that is rarely reported in patients with pulmonary arterial hypertension (PAH). Hemoptysis is reported to be a terminal stage of a complication due to PAH. The incidence of hemoptysis in $\mathrm{PAH}$ patients remains uncertain and tends to be unreported. Similarly, the patho-mechanism of hemoptysis in PAH remains uncertain. ${ }^{4}$

Pulmonary arterial hypertension (PAH) is a pathological condition whose primary cause originates from pulmonary circulation, where $75 \%$ of patients with $\mathrm{PAH}$ show evidence of bronchial artery hypertrophy on CT-Scan examination. The number of dilated bronchial arteries increases with increasing severity of PAH. These data suggest the hypothesis that the presence of bronchial artery hypertrophy increases the risk of hemoptysis in PAH patients. ${ }^{11}$

Hemoptysisis reported in $6 \%$ of $\mathrm{PAH}$ patients followed for 10 years in Poland. Other data from France suggest that the incidence of hemoptysis in PAH patientsoccurs in 1 for every 137 patients each year. Aside from bronchial artery hypertrophy, hemoptysis in patients with PAH can be derived from rupture of the pulmonary artery. There have been various reports of hemoptysis occurrence in patients with pulmonary arterial aneurysm or pseudoaneurysms. ${ }^{2,16}$

$\mathrm{PAH}$ is associated with a progressive dilatation of the pulmonary artery and an increase in intraluminal pressure, wherein the dilatation of the existing pulmonary artery will result in an increased risk of the patient to experience pulmonary artery rupture and followed by hemoptysis. In addition, it was found that in about $25 \%$ of patients with Pulmonary Artery Hypertension (PAH), there was a genetic mutation in the Bone Morphogenetic Protein type 2 Receptor (BMPR2) gene . The BMPR2 gene plays a role in regulating the growth, differentiation and apoptosis of epithelial and mesenchymal cells. The BMPR2 gene also plays a role in responding to the presence of trauma to cells. Damage or mutations in the BMPR2 gene causing decreased blood vessel stability. As a result, PAH patients with mutations in the BMPR2 gene are likely to have unstable pulmonary and bronchial blood vessels, thus increasing the risk of rupture of the blood vessels resulting in hemoptysis. ${ }^{5,4}$

In patients presented in this case report, recurrent episodes of hemoptysis make the patient several times hospitalized. Patients have been screened for tuberculosis from sputum examination, Chest x-ray, and Thorax CT-Scan to exclude the possibility of hemoptysis-associated tuberculosisor malignancy. From the results of the examination was not found evidence of tuberculosis infection and lung or respiratory malignancy.

Treatment of Hemoptysis Associated with Pulmonary Hypertension

In the 2015 ESC/ERS Guidelines for pulmonary hypertension, an algorithm of pulmonary arterial hypertension therapy is presented. Currently, several studies for the treatment of pulmonary hypertension have been performed, such as class of vasodilators, prostanoids, nitric oxide, phosphodiesterase inhibitors, endothelin receptor antagonists and anti-coagulants treatment. ${ }^{1,3}$

Based on existing studies, it was found that in patients with idiopathic pulmonary arterial hypertension who responded well to acute vasodilator (oxygen test) during right heart catheterization, only a small proportion responded well to calcium channel blockers. Calcium-blocking drugs have been studied in patients with pulmonary hypertension, including 
nifedipine, diltiazem and amlodipine. Selection of calcium-blocking drugs was based on the patient's initial heartbeat, whereas in patients with relative bradycardia, nifedipine and amlodipine were selected, whereas patients with relative tachycardia were given treatment options with diltiazem. ${ }^{17}$ Rich et al., 1992 studied the use of Calcium Blockers in $\mathrm{PAH}$ patients $95 \%$ of patients survived for 5 years. Use of verapamil should be avoided because of its negative inotropic effect. The use of the above drug causes significant adverse events such as severe hypotension that can be life-threatening to the patient, requiring rigorous monitoring of patients' hemodynamics. ${ }^{18}$ In patients reported in this case report were not treated with a calcium-blocker group because from an acute vasodilator test (oxygen test) showed non-reactive results.

Bosentan is included in the class of endothelin receptor antagonists (ERAs). Bosetan is used in medicine because of much evidence about the role of endothelin-1 in the pathogenesis of pulmonary hypertension. Endothelin-1 is a potent vasoconstrictor and a smooth muscle mitogen which contributes to increased vascular tone and pulmonary vascular hypertrophy associated with pulmonary hypertension. ${ }^{19}$ In patients with $\mathrm{PAH}$, elevated endothelin-1 and its plasma products were obtained. It is associated with the severity of the disease. The first randomized, double-blind, placebo-controlled, and multicenter study with bosentan $62.5 \mathrm{mg}$ twice daily for the first four weeks, continued to a dose of $125 \mathrm{mg}$ twice daily. Patients in the study were severe idiopathic $\mathrm{PAH}$ or $\mathrm{PAH}$ with scleroderma who experienced heart failure in accordance with functional categories Class III \& IV according to NYHA. The use of bosentan, showed improvement in the heart index, decreased the median value of pulmonary artery pressure and improved the category of heart failure according to NYHA. ${ }^{19}$
Sildenafil, including the phosphodiesterase inhibitor group, is a specific phosphodiesterase type 5 inhibitor. Formerly known as a drug used for erectile dysfunction. The study of 278 patients with idiopathic $\mathrm{PAH}$ and $\mathrm{PAH}$ with connective tissue abnormalities or with corrected cardiac congenital abnormalities, using placebo or sildenafil (20.40 and $80 \mathrm{mg}$ ) administered orally three times daily for 12 weeks. In the group using sindenafil there was a decrease in mean artery pulmonary pressure (mPAP). ${ }^{20}$ The FDA approved sildenafil to decrease pulmonary artery pressure in $\mathrm{PAH}$ at a dose of $20 \mathrm{mg}$ three times daily. Higher doses can mPAP, but high doses in the long term cause side effects dizziness, headache, epistaxis, nausea and vomiting. ${ }^{21}$

Hemoptysis is known to be one of the complications of pulmonary hypertension. Although the incidence is quite rare, the presence of recurrent hemoptysis in patients with pulmonary hypertension is a sign of poor prognosis. Hemoptysis is generally a complication of pulmonary hypertension, especially subtype: hereditary pulmonary hypertension, pulmonary hypertension associated with congenital heart disease and chronic thromboembolic pulmonary hypertension. The severity of hemoptysis in patients with pulmonary hypertension varies from mild to severe which can result in sudden death. The prevalence of hemoptysis complication in patients with pulmonary hypertension varies from $1 \%$ to $6 \% .4,5$

Based the 2015 ESC/ERS Guidelines for pulmonary hypertension, Bronchial artery embolization is recommended as an immediate emergency procedure in patients with severe hemoptysis pulmonary hypertension, or as an elective intervention in mild-to-moderate hemoptysis with a frequency episode. Anticoagulant therapy in patients with pulmonary hypertension with hemoptysis episodes should be postponed for a time. ${ }^{1}$ In this case report, patients were not undergoing bronchial artery 
embolization procedures, because during hospitalization the hemoptysis complaints improved with pharmacological therapy.

Prognosis of Hemoptysis Associated with Pulmonary Hypertension

The prognosis of $\mathrm{PAH}$ is usually worse because it is generally caused by other diseases. Usually, patients realize if they have pulmonary hypertension after the clinical symptoms appear, which that means the patient is already in an advanced stage. If it was diagnosed earlier, the prognosis will be better, at least in terms of reducing symptoms. Hemoptysis is known to be one of the complications of pulmonary hypertension. Although the incidence is quite rare, the presence of recurrent hemoptysis in patients with pulmonary hypertension is a sign of poor prognosis. ${ }^{4,5}$

\section{Conclusion}

It has been reported 25 -year-old female patients with non-reactive $\mathrm{O}_{2}$ test of Primary Pulmonary Hypertension and observation of hemoptysis suspected to be associated with pulmonary hypertension. Hemoptysis is a serious complication that is rarely reported in patients with pulmonary arterial hypertension (PAH). Hemoptysis are reported to be a terminal stage of a complication due to PAH. The incidence of hemoptysis in $\mathrm{PAH}$ patients remains uncertain and tends to be unreported. Similarly, the pathomechanism of hemoptysis occurrence in PAH remains uncertain. Although the incidence is quite rare, the presence of recurrent hemoptysis in patients with pulmonary hypertension is a sign of poor prognosis. Based on the $2015 \mathrm{ESC} /$ ERS Guidelines for pulmonary hypertension, Bronchial artery embolization is recommended as an immediate emergency procedure in patients with severe hemoptysis pulmonary hypertension, or as an elective intervention in mild-to-moderate hemoptysis with a frequency episode.

\section{REFERENCES}

1. Galiè N, Torbicki A, Barst R, Dartevelle P, Haworth S, Higenbottam T. 2015.Guidelines on diagnosis and treatment of pulmonary arterial hypertension. The Task Force on Diagnosis and Treatment of Pulmonary Arterial Hypertension of the European Society of Cardiology. Eur Heart J; 25: 2243-78.

2. Humbert M, Sitbon $O$, Chaouat $A$, Bertocchi M, Habib G, Gressin V. 2006. Pulmonary arterial hypertension in France: results from a national registry. Am J RespirCrit Care Med; 173: 1023-30.

3. Farber HW, Loscalzo J. 2004. Pulmonary arteri hypertension, N Engl J Med; 351:165565

4. Zylkowska J, Kurzyna M, Pietura R, Fijalkowska A, Florczyk M, Czajka C, Torbicki A.2011. Recurrent hemoptysis: an emerging life-threatening complication in idiopathic pulmonary arterial hypertension. Chest;139:690-693.

5. Tio $D$, Leter $D$, Boerrigter $B$, Boonstra $A$, Noordegraaf AV, Bogaard HJ. 2013. Risk Factors for Hemoptysis in Idiopathic and Hereditary Pulmonal Arterial Hypertension. PLoS One Journal: 8: 1-11.

6. Simonneau G, Galie ' N, Rubin LJ, Langleben D, Seeger W, Domenighetti G, Gibbs S, Lebrec D, Speich R, Beghetti M. 2013. Clinical classification of pulmonary hypertension. J Am Coll Cardiol;43 (Suppl 1):S5-S12.

7. Edward WD and Edward JE. 1997. Clinical Primary Pulmonary Hypertension. Circulation; 1997; 56: 884-888.

8. Diah M, Ghanie A. 2006. Hipertensi pulmonal primer. Buku ajar ilmupenyakitdalam 3, ed 4. Pusat penerbitan Departemen IImu Penyakit Dalam Fakultas Kedokteran Universitas Indonesia;1697-1702.

9. McGoon M, Fuster V, Freeman W, Edwards W, Scott J. 1996. Pulmonary hypertension. 
In: Giuliani E, editors. Mayo Clinic practice of cardiology. St. Louis, MO Mosby: 1815-36.

10. Wolferen SA, Marcus JT, BoonstraA, Marques KM, Bronzwaer JG, Spreeuwenberg MD. 2007. Prognostic value of right ventricular mass, volume, and function in idiopathic pulmonary arterial hypertension. Eur Heart J; 28: 1250-7.

11. Grubstein A, Benjaminov $O$, Ben Dayan D, Shitrit D, Cohen M. 2008. Computed tomography angiography in pulmonary hypertension. Isr Med Assoc J. 10: 117-120

12. Hoeper MM, Lee SH, Voswinckel R, Pallazini M, Jais X, Marinelli A. 2006. Complications of right heart catheterization procedures in patients with pulmonary hypertension in experienced centers. J Am Coll Cardiol; 48:2546-52.

13. HerveP,Launay JM, Scrobohaci ML, Brenot F, Simonneau G, Petitpretz P. 1995. Increased plasma serotonin in primary pulmonary hypertension. Am J Med; 99: 249-54.

14. Thenappan T, Shah SJ, Rich S, M GombergMailand. 2007. A USA-based registry for pulmonary arterial hypertension: 1982-2006. EurRespir J; 30: 1103-10.

15. Badner, JL \&Pachner RW. 2005. Hemoptysis: Diagnosis and Management. AAFP Journal; 72: 1253-1260.
16. Hiraki T, Kanazawa S, Yasui K, Okumura Y, Dendo S, et al. 2004. Transcatheter embolization of pulmonary artery false aneurysm associated with primary pulmonary hypertension. Cardiovasc InterventRadiol 27(2): 186-189.

17. Sitbon O, Humbert M, Jai"s X, loos V, Hamid AM, Provencher S, Garcia G, Parent F, Herve P, Simonneau G. 2005. Long-term response to calcium channel blockers in idiopathic pulmonary arterial hypertension. Circulation;111:3105-3111.

18. Rich S, Kaufmann E, Levy PS. 1992. The effect of high doses of calcium-channel blockers on survival in primary pulmonary hypertension [see comments]. N Engl J Med;327:76-81.

19. Channick RN, Simonneau G, Sitbon O, Robbins IM, Frost A, Tapson VF. 2001. Effects of the dual endothelin-receptor antagonist bosentan in patients with pulmonary hypertension: a randomized placebo-controlled study. Lancet; 358: 1119-23.

20. Galie N, Ghofrani HA, Torbicki A, Barst RJ, Rubin LJ, Badesch D. 2005. Sildenafil citrate therapy for pulmonary arterial hypertension. N Engl J Med; 353: 2148-57.

21. Hoeper MM, Welte T. 2006. Sildenafil citrate therapy for pulmonary arterial hypertension. N Engl J Med; 354:1091-3. 